in State farms, collective farms, co-operatives or large groups of family units under one management. In China some 40 per cent of farms are less than 1.2 acres; in Japan two thirds are less than $2 \frac{1}{2}$ cucres. These little plots cannot produce proper food for the farmers' families. Some means must be found by which the density of the agricultural population can be reduced.

The production of sufficient food is only half the battle. The producer must know that his erops will find a market; the consumer must be able to buy the food produced. The whole reorganization must involve fundamental changes of custom and conflict with vested interests. Opposition may be less than it would have been a few years ago. All the world over, people are becoming familiar with food control ; in Great Britain they are beginning to realize its possibilities. Also hunger is a strong argument, and hunger is one of the few things of which there is prospect of plenty at the end of the War. An International Famine Relief Commission will wield a convincing weapon-food; if it uses this weapon justly and efficiently it can do much to reconcile people to profound changes. Difficulties are great; they must be studied now. For only those who know clearly what they want and how to get it are likely to achieve anything worth having in the welter of conflicting policies at the end of the War.

\section{INTERNATIONAL ECONOMIC EQUILIBRIUM}

$\mathrm{T}$ $\mathrm{HE}$ meetings of the Inter-Allied Council render one signal service in respect of reconstructionthey stress its international aspect. This has to some extent been overlooked in the studies and discussions on reconstruction which have so far been initiated in Great Britain, and for all the attention that has been given to the work of the Leith-Ross Committee and the establishment of the Leith-Ross Bureau to deal with problems involved in the storage of surplus foodstuffs and their distribution after the War to the peoples in enemy-occupied Europe, the economic aims stated in the fourth and fifth points of the Atlantic Charter have not received much emphasis. The political, economic and soeial aspects of international reconstruction cannot indeed be entirely separated. They are as interlocked as the international and the national or internal aspects of reconstruction, and our hopes of a new and stable world order depend largely on our exploring the situation now so as to lay bare the principles for a constructive policy in readiness for the time of action.

Much of that action must of necessity be deferred until after the War, though in certain matters preliminary action as well as the determination of broad lines of policy are already required. Demobilization, for example, clearly must receive consideration before the fighting ceases. Plans must be in readiness, and the experience of 1918 is with us as a warning that a sudden and unexpected collapse of the enemy should not again find us unprepared. Unpreparedness can as assuredly endanger the winning of the peace as it has hindered the organization of victory.

In the last year or so, the discussions which for the first year of the War were so prominent on Federal Union and the exact form of the organization of a collective security system have rather fallen into the background. It has been recognized that the final form of organization to be adopted is a question to be determined later. On the other hand, there is a wider recognition that forms of co-operation established to serve the common purpose during the War can equally contribute to the final purpose of winning the peace. Even before the United States entered the War, there was unmistakable evidence on both sides of the Atlantic of Anglo-American determination to maintain that co-operation, and the machinery now established will not be recklessly scrapped unless it is proved to be no longer serviceable.

Besides this, attention is being concentrated, not first on the machinery to be established, but rather on the problems to be solved, with the object of elucidating first principles and from them arriving at the methods and organization most likely to provide a solution. In the field of international reconstruction there is, for example, the problem of the relation of Great Britain to Europe. There is the problem of the place of Germany in a now European system. There are the questions of the colonial peoples and of raw materials, and there is the problem of reconstructing world trade.

All these problems are, of course, related and have at least some bearing on the organization of postwar relief in occupied Europe, as well as on the establishment of a new system of collective defence. None the less, they can each serve as the startingpoint for an attempt to arrive at first principles and to remove some of the causes of intermational friction which contributed to the outbreak of the present struggle. This is admirably illustrated in the survey of international economic relations which Prof. J. B. Condliffe has written under the title "The Reconstruction of World Trade"*.

Prof. Condliffe's volume falls naturally into three parts. The first analyses the collapse of the international trading system that was restored, on the pre-war model, after the War of 1914-18. The second, including much the most technical chapters, examines the challenge now presented by the totalitarian methods of bilateral trade. The third surveys the problems that must be faced in any attempt to reconstruct world trade after the War comes to an end. The book is based largely on material drawn from research studies undertaken in preparation for a conference called to meet at Bergen on August 27, 1939 , and much of it would normally have formed a report of the International Studies Conference on "Economic Policies in Relation to World Peace". It has, however, lost nothing of its pertinence in the interval, and this lucid exposition could scarcely be bettered as a guide to the discussion of trade policy

* The Reconstruction of World Trade : a Survey of Internationa Economic Relations. By Prof. J. B. Condliffe. (Prometheus Library.) Pp. 427. (London: George Allen and Unwin, Ltd., 1941.) 128. 6d. net. 
after the War to which Mr. J. G. Winant and Mr. Sumner Welles have recently made such pointed reference.

On the making of policy Prof. Condliffe writes forcefully in his opening chapter. He points out that a Government can rarely lay down in advance, and adhere to, a line of policy which is the result of mature judgment and reflection. Wherever action must be adjusted to an ever-changing set of circumstances largely beyond the control of any individual, group, or government, policy must be in large degree improvised and pragmatic. Moreover, a discussion of the forces that shape national economic policies in the international field cannot be narrowly confined to the field of commercial policy. Prof. Condliffe refers pointedly to the effect of private enterprise, and it follows from what he says that any serious attempt to achieve a balance between freedom and order in the national sphere, as has been suggested by Mr. Geoffrey Crowther, is bound to determine largely the nature of economic policy in the international field.

A further important factor is the passing of power in recent years from the legislative to the administrative side of government. This is widely recognized, but its bearing on economic policy has scarcely been examined, and the searching questions which Prof. Condliffe raises demand careful answer if our reconstruction of world trade is to proceed on sound lines. $\mathrm{He}$ stresses the real danger of the progressive withdrawal of day-to-day policy from detailed public scrutiny and criticism. The concentration of power exercised for long periods without the check of public criticism makes individual errors more serious, because errors of policy tend to become cumulative. Moreover, administrative control of policy-making puts a premium upon organized pressure from directly interested individuals or groups of individuals, and lessens the consideration likely to be given to the general public interest, and particularly the unorganized interest of the consumer.

These warmings cannot be lightly disregarded in respect of whatever new measures of commodity control may be developed even for the relief of occupied European countries. The conflict between national regulation and international equilibrium must be recognized, and while we may seek, as Prof. Staley has unged in "World Economy in Transition", to lessen the economic significance of national boundaries, the task of creating effective organs of international co-operation on a regulated basis must not be shirked. Meanwhile Prof. Condliffe's conclusion that the best practical prospect of restoring international equilibrium lies in the re-establishment of known and accepted routine lines of policy, based upon a relatively moderate degree of national planning in the sense of assuring to each national community reasonable minima of security and livelihood, is at least in keeping with the terms of the Atlantic Charter. World economic activity, like world peace, is in fact indivisible.

The relation of freedom of trade to the establish. ment of social security in the field of nutrition has already been emphasized in such studies as F. L.
McDougall's "Food and Welfare", and Prof. Condliffe's book shows how closely it is related to the wider aspects of security. Government policy, not economic or scientific developments, has been responsible for the great decrease in trade in agricultural products, both food and raw materials. The primary responsibility for the breakdown in international trade lies not with economic facts but with economic policy, arising from attempts to place the interest of particular groups before that of the community as a whole and, in particular, to preserve and buttress the un. fettered sovereignty of the national State.

International economic equilibrium is not a static but a dynamic concept, and we have yet to develop the appropriate organization and technique now that the technical progress of industry has outgrown national boundaries, as in an earlier age it outgrew the boundaries of city States. Social regression, not security, will follow from any attempt after the War to cling to traditional forms of political organization and put back the clock of scientific knowledge and industrial technique. The dangers inherent in modern tariffs and the complications of tariff bargaining, the administrative obstacles they introduce to trade and the extent to which they represent a reversion to tyrannical methods of government are unmistakable in this analysis. Bilateral treaties negotiated in recent years represent, on the whole, grave restrictions on multilateral trade, and the warm tribute which Prof. Condliffe pays to Mr. Cordell Hull's efforts to promote multilateral trade and breach the high pro. tective wall erected by the Howley-Smart tariff does not disguise the little that had been achieved in removing the obstacles to the restoration of world trade.

It must be recognized therefore that while attempts to preserve past privileges of occupation or ownership may wreck international co-operation in the future as they have done in the past, the absence of any real will-power has been the decisive factor. Policies of independent economic nationalism can never form the basis of co-operation. Their ultimate aim is world domination and their technique is that of conflict. No compromise is possible, in the long run, between States that are organized to serve the purposes of individual citizens and those in which the individual is subordinated to the service of the State.

Prof. Condliffe's thoughtful chapter on new aspects of international organization well illustrates the need for further investigation if we are to formulate a sound policy for the reconstruetion of world trade. We have to take account, not merely of the limitation or redefinition of national sovereignty but also of the tendency of business organization and trading relations to become international in scope. The importance of the borderland between business and government with regard to international relations has increased considerably and still presents one of the most significant fields for economic research. Moreover, experience gained with certain of the war-time controls can scarcely fail to prove invaluable for the correction of the weaknesses revealed in some of the pre-war international commodity control schemes and to increase our exact knowledge of their extent and relations with government regulation. If Prof. 
Condliffe does not visualize anything like the Raw Materials Union suggested by "Balbus" in "Reconstruction and World Peace" (Democratic Order Pamphlet No. 10) and in the P E P broadsheet, "Commodity Control Schemes", he at least sees the possibility of dealing with the consumer interests more fairly and effectively.

The extension or development of international commodity schemes is a difficult problem. There is no very satisfactory half-way house between a free trading system based on laisser-faire and one in which national production is co-ordinated in a system of international planning. Moreover, Prof. Condliffe has misgivings about the international planning of policy, for reasons already indicated, and while he considers there are wide areas of economic activity over which government control could with advantage be extended, such control should be limited to regulation rather than operation, and for this new types of international political and economic institutions must be invented. Indeed, the possibilities of international economic co-operation in the immediate future will largely depend on the way in which governments use such powerful new instruments as credit regulation.

While the necessities and disillusions which follow a great war may be powerful factors of constructive co-operation, that only holds if they are used in that direction. Peace is a dynamic process, the other name for which is co-operation, and only a world which is prepared to make the continuous effort of re-creating peace, like freedom, year by year, can establish and maintain a new international system of economic co-operation and social security. The most hopeful feature of that Anglo-American co-operation which has developed during the last fifteen months has been the frank indication on both sides of the intention to see it to completion.

Prof. Condliffe recognizes the paramount influence of the United States on any international system which can be established, and that it must be based on Anglo-American co-operation. $\mathrm{He}$ touches on those other problems of the position of Britain in Europe which also affect the ultimate solution, and stresses that the choice before us is broadly one between entering a European confederation or join. ing with the United States in an effort to re-establish a world trading system. But it is less for the outline of a suggested solution of the problem than for its clear analysis of principles, its firm warnings of the dangers that cumber the way, its challenge to searching inquiry and constructive thought that Prof. Condliffe's book is an outstanding contribution to the discussions which Mr. Winant, Mr. Cordell Hull, Mr. Sumner Welles and others have already initiated.

The guarded language which Lord Cranborne necessarily used in November in replying to a question in the House of Lords regarding the methods by which the Government proposes to give effect to Article V of the Atlantic Charter and to secure the fullest collaboration between all nations in the economic field should not be taken as indicating that the Government is not alive to the importance of this subject and anxious to secure the improved labour standards, economic advancement and social security implied therein. Practical plans of economic cooperation already engage its attention, and the growing ties between the two great democracies should ensure that they will face together now, and not merely after the War, the broad changes of policy involved in the inevitable internal and external reconstruction. Moreover, in approaching and studying these problems it must be remembered that by the adhesion of the Soviet Union and of the Allied Governments now in London, the Atlantic Charter has become a multilateral pact. The co-operation of twenty-six nations in fighting aggression is already pledged thereby to continue after victory is won to ensure that the world shall gather its fruits in peace and in security.

The immediate task in regard to world trade is of course to create the international machinery for co-operation after the War to enable people to live, to find the means of livelihood, and to exchange their products with one another, and to arrive at common understanding as to the principles on which such machinery shall operate in the conditions likely to obtain at the end of the War. The impartial examination of practical problems in a new setting, without regard to theories or dogmas framed to meet other conditions, should be able to evolve plans for preventing a repetition of the chaos which followed 1918. The four freedoms will only be established by planning and co-operation and an immense amount of hard work, in which the reconstruction of world trade is one of the first steps to the establishment of that freedom from want, which in Mr. Winant's view should be one of our first objectives after the War. There should be no lack of response in Great Britain to the efforts already being made in the United States in the study of these problems, so as to extend the present co-operation after the War into the organization of the exchange of goods on co-operative instead of on narrowly competitive lines.

\section{WEATHER ANALYSIS AND FORECASTING}

\section{Weather Analysis and Forecasting}

A Textbook on Synoptic Meteorology. By Prof. Sverre Petterssen. Pp. xvi+505. (New York and London: McGraw-Hill Book Co., Inc., 1940.) 35s.

FOR twenty years the Norwegian school of meteoro-

logy has led the world in the development of methods of forecasting. The appearance of a treatise on weather analysis and forecasting by a distinguished member of the school is therefore an important event. Prof. Sverre Petterssen was for many years on the staff of the Geophysical Institute at Bergen and recently succeeded Prof. C. G. Rossby as professor of meteorology at the Massachusetts Institute of Technology. His book developed from courses of lectures delivered during the years 1935-40 at various places in America and Norway.

Long before the influence of the Norwegian school was felt, meteorologists realized that the weather was influenced largely by the interplay of currents of air 